\title{
GLOBALNO ZDRAVLJE I INTERES DRŽAVE
}

\section{Petar Popović}

Fakultet političkih znanosti Sveučilište u Zagrebu

E-mail: petar.popovic@fpzg.hr
DOI: 10.20901/an.17.05

Pregledni rad

Prihvaćeno: listopad 2020.

\begin{abstract}
Sažetak Pandemija koronavirusa posljednja je u nizu svjetskih kriza koja upućuje na domete i ograničenja teorija međunarodnih odnosa, poglavito suvremenog realizma. Konvencionalni analitički okvir koji međunarodne političke odnose svodi na dvije razine, nacionalnu i međunarodnu, čini se nedostatnim u razmatranju globalnog upravljanja zdravljem. Ovaj rad namjerava, iz perspektive teorija globalizacije, ukazati na kompleksan karakter i logiku globalnoga prostornog poretka na području zdravlja. Implikacije za državu i njezin interes ogledaju se u dramatičnoj proliferaciji različitih privatnih aktera, od farmaceutske industrije do korporativnih i filantropskih inicijativa. Njihovom se ekspanzijom poglavito zapadne gospodarske i vojne sile pozicioniraju na prostoru moći u globalnom upravljanju. No tržišna logika i difuzna moć globalnog zdravlja generiraju ekstremne zdravstvene neravnoteže među razvijenima i nerazvijenim društvima, jakima i slabim državama. Globalan nerazmjer, odnosno katastrofalni sanitarni uvjeti u Trećem svijetu uzroci su potencijalnih izbijanja pandemija koja ugrožavaju globalni poredak. Ključno je stoga pitanje što je uopće strateški interes države u epohi globalnog zdravlja.
\end{abstract}

Ključne riječi globalno upravljanje, globalno zdravlje, država, interes, međunarodna organizacija

\section{Uvod}

Dalekosežne političke posljedice pandemije koronavirusa 2020. godine urgentan su spoznajni izazov za disciplinu međunarodnih političkih odnosa. Pandemija je gotovo paralizirala globalne institucije pa se realistička teorija očekivano nametnula kao najpogodniji eksplanatorni okvir. Istaknuti realist Steve Walt smatra kako pandemija koronavirusa potvrđuje snagu središnjega realističkog postulata da su države glavni akteri koji u trajno nesigurnom svijetu uvijek teže povećanju vlastite moći. Međunarodna suradnja zasigurno postoji, ali je čovječanstvo kao jedinstven subjekt na zajedničkom bojištu protiv globalne pandemije puka iluzija. Suradnja je država krhka zbog neumoljivog zakona sigurnosne dileme: "Država strahuje kako se drugi ili neće držati svojih obveza, ili kako će se okoristiti suradnjom" (Walt 2020). S pandemijom se "realizam vratio u velikom stilu". Zatvaranje granica, uvođenje karantena, zabrane putovanja i druge mjere upućuju na rastući trend unilateralnih odluka, kako autoritarnih režima tako i SAD-a i pojedinih država-članica Europske unije (Karačić 2020). Robert Mikac (2020) slično tvrdi 
da realizam najbolje objašnjava "novu realnost" u kojoj se ističe snaga države u upravljanju krizom u nacionalnim resorima po cijenu "vrlo ograničene suradnje s drugim državama". Suradnja nije samo ograničena nego je, prema mišljenju Fredericka Kleima (2020), države otvoreno miniraju. Države se okreću sebi, a na štetu međunarodne organizacije: od toga da se države natječu u tome koja će samostalno provoditi uspješnije epidemiološke mjere do ekstremnih slučajeva kao što je odluka Trumpove administracije da povuče SAD iz Svjetske zdravstvene organizacije (WHO).

Pitanje pandemije eminentno je političko pitanje koje kompleksnošću nadilazi banalno isticanje gole moći te zahtijeva smještanje države kao glavnog aktera, njezinih motiva i interesa u širi kontekst. Pandemija je ponajprije politički problem globalnog upravljanja zdravljem. Općenito, pojam globalnog upravljanja (global governance) vrlo je teško odrediti jer obuhvaća prostor bez hijerarhije i utvrđene raspodjele odgovornosti, ali i s nepredvidivim ishodima (Aginam 2005; Kamradt-Scott 2013; Leon 2015). Na prostoru globalnog zdravlja procese više ne oblikuju samo države ili međunarodne organizacije, poput WHO-a. Na tom prostoru djeluje više od četrdesetak bilateralnih donatora, dvadeset pet UN-ovih agencija, dvadesetak što globalnih, što regionalnih fondacija, te oko devedeset globalnih zdravstvenih inicijativa (Council on Foreign Relations 2019). Umreženost i privatno-javna međuovisnost moći i interesa dokidaju pojednostavnjeni analitički konstrukt o dvjema konstitutivnim sferama politike: nacionalnoj i međunarodnoj. Globalni je prostor sfera onkraj obje. Tradicionalni realističko-liberalni prijepor o opredjeljenjima za jaku državu ili međunarodnu suradnju samo je jedna, u biti sekundarna, dimenzija te problematike. Stoga je analitički primje- reno izaći izvan disciplinarnih teorijskih okvira međunarodnih političkih odnosa i kročiti na područje sociologije globalizacije.

Nije sporno da je država glavni akter na međunarodnoj pozornici. Ona polaže legitimno pravo na primjenu sile, posjeduje administrativni aparat $\mathrm{i}$ sredstva nadzora, tumači pravo i donosi zakone. Te "tvrde" činjenice čine državu jedinstvenim političkim prostorom na određenenome geografskom mjestu državnom teritoriju. No prostor i mjesto nisu istoznačnice (Giddens 1990; Raos 2014; Zorko 2018). Mjesto je geografski položaj, to jest određeni i u političkom smislu omeđen lokalitet. Prostor je pak fluidna apstrakcija koju oblikuju ideje, društvenih aktivnosti i sadržaji. Kao takav, prostor je potencijalno neograničen; prostor se može, ali i ne mora odnositi na neko konkretno omeđeno mjesto. Interes države oblikuje se na temelju stanovitih percepcija političkog prostora, pa oznaka "nacionalni" ne znači nužno da je uvjetovan mjestom. Ipak, teorije međunarodnih odnosa općenito, a realizam posebno, inzistiraju na interesu države kao refleksiji strogo poistovjećivanog prostora i mjesta. Posljedica je to predodžbe koja je duboko utemeljena u europskome povijesnom iskustvu vestfalskoga prostornog poretka koji je bio, u smislu ondašnjega međunarodnog prava, određen i uvjetovan djelovanjem omeđenog mjesta, dakle suverene države. Međutim, globalni se prostor bitno razlikuje od vestfalske anarhije.

U prvom ću dijelu ovog rada razmotriti povijesne pretpostavke globalnog zdravlja u kontekstu globalizacijske preobrazbe države i javnog zdravstva. Taj proces svoj idejni izraz nalazi u WHOovoj proklamaciji iz 1946. o "potpunom zdravlju" čovječanstva. Drugi dio objašnjava logiku globalnog zdravlja kao prostora koji povratno preobražava ulogu države i njezin interes. Pokazat će 
se da države svjesno napuštaju tradicionalno tumačenje pojma "nacionalnog interesa" kako bi se pozicionirale na globalnom planu kroz umreženje s raznim akterima, od farmaceutske industrije do raznih privatnih inicijativa. To dovodi do središnjeg problema ovog rada: nije pitanje je li interes država održavanje globalne zdravstvene sigurnosti i "potpunog zdravlja", nego je li takav interes u doba globalizacije uopće moguć. Naime, pandemije su posljedica ekstremne neravnoteže u globalnom zdravlju među razvijenima i nerazvijenim državama. Siromaštvo i nerazvijeni sustav javnog zdravstva u Trećem svijetu pogoduju širenju virusnih zaraza koje, u kontekstu globaliziranog svijeta, prijete pandemijama globalnih razmjera. Za razvijeni Zapad, neravnoteža nije samo moralna dvojba nego i egzistencijalno pitanje. No, kako država može oblikovati interes na prostoru difuzne moći isprepletnih javnih i privatnih interesa?

\section{Povijesne pretpostavke globalnog zdravlja}

Kada je u Parizu 1851. sazvan prvi međunarodni sanitarni kongres radi sprječavanja pandemije kolere, nacionalne interese na području međunarodnog zdravlja određivala je teritorijalna logika realne politike. Vestfalski duh stoljećima je generirao kulturu omeđivanja nacionalnog interesa, relativne dobiti i političke ravnoteže moći. U svim pitanjima međunarodne politike, od međunarodnopravnih ugovora i rata do diplomacije i uspostavljanja ravnoteže, on se vodio općim načelom ograničavanja. Sukladno tomu, i bolest se politički "omeđuje". $\mathrm{Na}$ međunarodnome sanitarnom kongresu u Parizu 1903. zaključeno je da je žutica unutarnji problem Sjeverne Amerike s kojim se Amerikanci sami moraju nositi. Od 187 usvojenih članaka konvencije, samo se jedan odnosio na žuticu (Howard-Jones 1975: 85). Me- đunarodni sanitarni kongresi politički problem pandemija strogo ograničuju na tri prijetnje: koleru, kugu i žuticu. Kada je pri kraju Prvoga svjetskog rata izbila španjolska gripa, zarazivši trećinu svjetske populacije i odnijevši između pedeset i sto milijuna života, pododbor sanitarnog kongresa za pandemije teškom je mukom, nakon više rasprava, priznao gripu kao prijetnju. No riječ je o iznimci. Japan je 1926. predložio da se i vodene kozice označe prijetnjom od međunarodnog značenja, ali je prijedlog odbijen. Takav se zahtjev smatrao apsurdnim zbog činjenice što, kako je izjavio švicarski predstavnik, "nema te države u kojoj nema slučajeva vodenih kozica" (Howard-Jones 1975: 98).

Ipak, snaga "barokne politike" u vestfalskoj tradiciji niti kontrolira niti može utjecati na dinamične procese društvenog razvoja svijesti i ideja te preobrazbi unutarnjih sadržaja prostornog poretka. Zapadni civilizacijski krug, koji se od druge industrijske revolucije ubrzanije povezivao na osnovi tehnološkoga i industrijskog napretka, svjedoči o onome što Anthony Giddens naziva "odvajanjem prostora od mjesta" (Giddens 1990, pogl. 1). Razvojem kapitalizma i njegovim postupnim širenjem stvara se "prazan prostor" koji popunjavaju trgovinska, tehnološka i institucionalna isprepletenost i međuovisnost. Taj je prostor oblikovan sadržajima koji nisu vezani ni za jedno konkretno mjesto. Doduše, javno zdravstvo nije bilo zahvaćeno tim procesima makar do sredine 20. stoljeća. Ono je imalo status "niske politike", što znači da je zdravlje još uvijek bilo u nadležnosti lokalnih nacionalnih institucija koje brinu o stvarima poput osiguravanja čiste vode ili programa cijepljenja (Davies 2010: 1172). Korjenite promjene zbivaju se tek poslije svršetka Drugoga svjetskog rata kada očitim postaje epohalni preobražaj prostornog poretka svijeta. Hladnoratovska polari- 
zacija na kapitalistički Zapad i komunistički Istok nakon 1945. predstavljala je potpuno novu teritorijalnu diferencijaciju i raskid s vestfalskom državom kao teritorijalnim subjektom.

$\mathrm{U}$ novome bipolarnom poretku nemalu je ulogu imala Organizacija ujedinjenih naroda (OUN) u sklopu koje nastaje Svjetska zdravstvena organizacija kao njezina specijalizirana agencija za međunarodno zdravstvo. Prvi direktor WHO-a, dr. Brock Chisholm, naglasak je stavljao na zdravlje kao "društvenu dobrobit", istaknuvši kako je za spas čovječanstva nužno oblikovati bitno nov tip građanina koji će biti "lojalan samo svijetu" (Yi-Jui Wu 2015). U prvom nečalu svojega konstitutivnog akta iz 1946. WHO definira zdravlje kao "stanje potpune fizičke, mentalne i društvene dobrobiti, a ne tek odsustvo bolesti ili slabosti" (Charter of World Health Organization, 1946). James Larson je ukazao na to kako je koncepcija "potpuno zdravog" čovjeka utopijska apstrakcija koja, odnoseći se na sve, ustvari se ne odnosi ni na što. Sve što se ne uklapa u okvir percepcije o "potpunom zdravlju" potencijalno se može označiti bolešću. Zdravlje, međutim, nije svuda percipirano na jednak način. Primjerice, u Africi su pojedine bolesti, poput pupčane kile, toliko proširene da ih lokalno stanovništvo ne smatra bolestima (Larson 1996: 183). Pred državom i međunarodnom organizacijom ispriječio se ozbiljan operativni problem: budući da je ukinuto teritorijalno načelo, nastala je zbrka u prioritetima. Nestaje razlika između stvarnih opasnosti od prenosivih virusa i, za međunarodni poredak relativno nebitnih, neuroloških ili fizičkih bolesti svojstvenih određenom podneblju.

WHO-ova doktrina "potpunog zdravlja" donekle je sljednica međuratne doktrine prethodno propale zdravstvene organizacije Društva naroda. Pakt te organizacije posve je neodređeno nalagao članom 23 (f) da će države-članice poduzeti mjere "prevencije i kontrole bolesti" (The Covenant of the League of $\mathrm{Na}$ tions, 1924). U praksi je to značilo - ili je makar trebalo značiti - preuzimanje odgovornosti za ukupno međunarodno zdravlje od strane jedne potpuno depolitizirane organizacije koju su činili isključivo stručnjaci (Borowy 2009). Stoga se od početka činilo da će WHO zbog pretjeranog idealizma doživjeti jednaku ili sličnu sudbinu svoje prethodnice pod naletom moći političkih interesa velikih sila. Neposredno nakon osnutka, WHO potpada pod američki utjecaj, zbog čega je Sovjetski Savez sa svojim satelitima 1949. privremeno napušta (Fee, Cueto, Brown 2016). No rano se hladnoratovsko pozicioniranje snaga zbiva u kontekstu koji je uvelike odstupao od dotadašnje vestfalske logike, a ta se činjenica itekako tiče i javnog zdravstva. Na svim društvenim područjima unutar zapadnog bloka i njegove interesne sfere, pa tako i na području zdravlja i higijene, na djelu je proces "odvajanja prostora od mjesta".

Osnivanjem Bretton-Woods sustava (Svjetske banke i Međunarodnoga monetarnog fonda) 1944, interes zapadnih političkih elita bilo je trajno održavanje društvenog blagostanja. Nakon traumatičnog iskustva dvaju svjetskih ratova, mehanizmom Bretton-Woodsa sprječavalo bi se, uz poslijeratnu obnovu i poticanje ekonomskog rasta, širenje sovjetske "crvene prijetnje". Proklamirana koncepcija "zdravog društva" stoga je bila iznimno važna te je postala predmetom znanstvenih istraživanja psihopatologije. Spoznajom čovjekove društvene prirode i njegova ponašanja, eksperti WHO-a nastojali su proniknuti u psihološke korijene totalitarizma kako se iskustvo Drugoga svjetskog rata, posebice u kontekstu rođenja nuklearne ere, ne bi ponovilo (Larson 1996: 190). U prvim desetljećima zdravstvena dobrobit 
društva bila je isključivo u nadležnosti WHO-a i Američke agencije za međunarodni razvoj, koja je donirala golema sredstva za razvoj lokalnih infrastruktura javnog zdravstva. Nakon što je čelno mjesto u Svjetskoj banci preuzeo Robert McNamara 1968, ta je institucija prvi put proširila svoju praksu davanja zajmova za zdravstvo, higijenu i obrazovanje (Ruger 2005). Ako Svjetska banka ili bilo koja druga organizacija daje zajam ili pomoć, onda mjesto više ne diktira uvjete prema svojem interesu i potrebi. Nadnacionalnom intervencijom $\mathrm{u}$ sustav lokalnog zdravlja de facto počinje postupan proces deteritorijalizacije javnog zdravstva u skladu s univerzalnim načelom "potpunog zdravlja". U zapadnom bloku i njegovoj interesnoj sferi počinju iščezavati tradicionalne sanitarne prakse, koje su do tada bile svedene na životne navike pojedinca, odnos $s$ njegovim lokalnim liječnikom i radom nacionalnih domova zdravlja (Davies 2010: 1169).

WHO-ov zahtjev stoga nije bio naivan idealizam, nego pragmatično redefiniranje interesa države u kontekstu hladnoratovskih napetosti. Budući da, prema novoj doktrini, zdravlje nije samo "odsustvo bolesti", napušta se političko ograničavanje na određene, isključivo prenosive, bolesti. Time je načelo "potpunog zdravlja" stvorilo pretpostavke za neograničenu politiku interveniranja i oblikovanja svjetskog zdravlja. Pretpostavka postaje zbiljom s padom komunizma 1989-1991. te s nestankom posljednjega alternativnog prostornog poretka. Globalnom protežnošću kapitalističke nadnacionalne sfere - prostora "slobodnog protoka ljudi, roba i usluga" - zdravstvo gubi status "niske politike". U sferi kompleksne međuovisnosti sve, pa tako i zdravlje, postaje potencijalnim izazovom globalnom poretku. Globaliziranje zdravlja nije nametnuto - ono je bilo nužna posljedica svjetskih okol- nosti. Naime, slobodno i neograničeno kretanje ljudi i stvari uključuje i slobodno kretanje virusa. Od kraja Hladnog rata godišnje se prosječno otkriju dva nova infektivna patogena (Woolhouse i dr. 2008). Pandemije izbijaju jedna za drugom: HIV/AIDS 1981, "kravlje ludilo" 1996, virus "zapadnog Nila" 1999, SARS 2003, H5N1 ili "ptičja gripa" 2006, H1N1 ili "svinjska gripa" 2009, MERS 2012, ebola 2014 te Covid-19 (koronavirus) 2020.

\section{Globalizacijsko redefiniranje države i njezina interesa}

Globalno upravljanje zdravljem nije samo nepodnošljiv izazov realističkom pogledu na međunarodnu politiku, koji zbog odvajanja prostora od mjesta gubi čvrsto analitičko uporište u strogo teritorijalnoj predodžbi države, nego i liberalnom internacionalizmu. Globalno upravljanje nadilazi tradicionalno shvaćanje međunarodne suradnje. Na mjesto liberalnog internacionalizma stupa nova teorija/ideologija - globalizam. Rüdiger Safranski naveo je najmanje tri inačice te ideje: neoliberalnu, protunacionalističku i kozmopolitsku. Sve tri polaze od jedinstvene "slike svjetskog društva", prema kojoj se država doživljava kao prepreka individualnoj slobodi i dobrobiti u općem smislu. Zanemaruju se razlike u kulturama i običajima, kao i u nejednakim razinama društvenog razvoja. Za globalizam, to su samo "prijelazne faze" u napretku čovječanstva. Globalizam je "u biti više zahtjev i želja nego opis stvarnosti" (Safranski 2008: 17-18). Za tu je raspravu ključna prva, neoliberalna varijanta. Prema toj perspektivi, zdravstvena se dobrobit neće postići kolektivnom akcijom nevladinih ili međunarodnih organizacija ili svjetskom solidarnošću. Naprotiv, potrebno je omogućiti nesmetano kretanje kapitala i podređivanje države i društva ekonomiji te stavljanje naglaska na tržište kao je- 
dinog jamca opće dobrobiti. Korisno je ukratko prikazati globalistički ideološki rezon koji vjerno dočarava "duhovni" karakter prostora globalnog zdravlja.

Prema švedskom intelektualcu Johanu Norbergu, globalno bi upravljanje zdravljem napokon trebalo do kraja depolitizirati i prepustiti tržištu. Od države, s tromom birokracijom i korumpiranim političarima, kao i od međunarodne organizacije, koja nije ništa drugo do birokratizirano udruženje više država, ne treba očekivati ništa. WHO bi mogao $\mathrm{u}$ kratkom roku iskorijeniti tuberkulozu i malariju ako izdvoji od četiri do 220 milijuna dolara, odnosno 0,4 posto svoga godišnjeg proračuna: "Ali dok djeca nepotrebno umiru, WHO troši godišnje više od milijarde dolara na ekskluzivne konferencije i kampanje za, primjerice, promociju važnosti vezanja pojasa u vožnji ili prestanak pušenja" (Norberg 2003: 189). Norberg, nasuprot tome, sve nade polaže $u$ farmaceutsku industriju. U javnosti, doduše, ne postoji sektor koji budi tolike prijepore, oštre kritike i moralne dvojbe kao što su farmaceutske tvrtke, odnosno njihova dobro znana praksa patentiranja lijekova (Moerman i Van der Laan 2006; Hoen 2009). Intelektualno vlasništvo farmaceutskim tvrtkama daje pravo da podižu cijene svojih proizvoda iznad kupovne mogućnosti onih kojima su ti lijekovi najpotrebniji - dakle, nerazvijenim društvima Trećeg svijeta. Međutim, Norberg kaže kako bi ukidanje patenta imalo samo kratkoročan učinak. Patenti su, naime, razlog zbog kojega ti lijekovi uopće postoje. Prosječno, navodno, propadne od dvadeset do trideset lijekova dok se ne proizvede jedan uspješan lijek, a takva istraživanja koštaju stotine milijuna dolara. Visoka je cijena nekolicine lijekova nužna: "Kada bi se ukinuli patenati, teško da bi ijedna tvrtka mogla nastaviti istraživati i proizvoditi lijekove" (Norberg 2003: 187-188).
Odatle se iščitava da je logika globalnog upravljanja zdravljem tržišna logika. Budući da se prema prirodi svojih ograničenja država i međunarodna organizacija ne uklapaju u uniformnu predodžbu svjetskog društva, uređenoga prema zakonima globalne ponude i potražnje, obje se doživljavaju kao zastarjeli i prevladani oblici - prepreke istinskom napretku čovječanstva. U osnovi je globalističke averzije prema nacionalnoj državi negacija mjesta/teritorija. Zbog svoje statičnosti, lokalitet nema druge vrijednosti i svrhe osim da bude eksploatiran za potrebe globalno deteritorijaliziranoga svjetskog tržišta. No činjenica čvrstog tla se može poricati, ali ne i odstraniti. Potpuno deteritorijaliziran prostor jest čista apstrakcija, teorijski konstrukt jedne ideologije, koji u praktičnoj zbilji ima jednu jedinu posljedicu - reteritorijalizaciju (Zorko 2018: 38). Reteritorijalizacija je neminovan učinak povratnog oblikovanja mjesta/teritorija od odvojenog prostora/ globaliteta. Prema Giddensu, učinak na mjesto "nije jednostavno ono što je na sceni prisutno: "Vidljiv oblik lokaliteta skriva udaljene odnose koji određuju njegovu prirodu" (Giddens 1990: 19).

Globalitet preoblikuje državu koja, prema Ulrichu Becku, postaje "glokalnom državom" ili "provincijom svjetskog društva". Koliko god se moderna koncepcija nacionalne države čini zastarjelom, ona je neophodna, "i to ne samo zato što jamči unutarnju politiku i geopolitiku, osnovna politička prava itd., nego i zato što politički oblikuje proces globalizacije i nadnacionalno ga regulira" (Beck 2003: 256). Na tom tragu, Saskia Sassen (2003: 29-30) ukazuje na to da u procesu preoblikovanja država napušta tradicionalnu racionalnost državnog razloga (raison d'etat) smanjivanjem vlastitih ovlasti posredstvom deregulacije tržišta, ekonomije i svojih granica te privatizacijom javnih tvrtki. 
Privatizacija norme kao "nova normativnost" države oblikuje interes koji "dolazi iz svijeta privatne moći, no smješta se u javni prostor... Državne institucije pomažu preusmjeravanju vlastitoga političko-strateškog djelovanja ili, šire, državnih agendi prema zahtjevima globalne ekonomije" (31). Drugim riječima, slabeći institut suverenosti ekonomskom liberalizacijom, država istodobno povećava svoju moć na globalnom planu. Naime, neoliberalno "slabljenje" deregulacijom država dopušta samo na području ekonomije i financija. Pritom zadržava legitiman monopol nad sredstvima kontrole, prisile, tumačenja prava i proizvodnje legalnosti. Odatle slijedi da moć privatnog kapitala i dominacija korporativnog svijeta nisu moguće bez države, samo što ključ njezine moći nije više, kako tvrde realisti, vojna snaga nego položaj na svjetskom tržištu.

Upadljiv je slučaj zakona o patentiranju lijekova. Tijekom osamdesetih godina 20. stoljeća farmaceutski je kartel u SAD-u uspostavio nevjerojatan savez s neoliberalnom administracijom predsjednika Ronalda Reagana - nevjerojatan je bio zato što je koncept intelektualnog vlasništva u bitnom smislu monopolistički i, kao takav, u suštoj je opreci ideji slobodnog tržišta. No, kako je pokazao David Tyfield (2010: 68), farmaceutska je industrija, u dosluhu $s$ vodećima medicinskim fakultetima i biotehnološkim tvrtkama, obećala američkima političkim elitama "tehnologiju budućnosti" kojom će se riješiti kronična neprofitabilnost u tom sektoru. Budući da samo država tumači i donosi zakone sukladno svojem interesu - u ovom slučaju, sukladno svojemu neposrednom tržišnom interesu - uvedene su stanovite zakonske preinake kako bi se dodatno pogodovalo farmaceutskoj industriji. Prvo, patentiranje se, definicijski, provodi samo ako je posrijedi neko novo otkriće. No biološki materijal nije otkriće pa se, prema novom tumačenju, patentira znanstvena inovacija. Drugo, patent je privatna stvar znanstvenika. No ako znanstvenik radi u instituciji koja se financira javnim novcem, njegov je patent potencijalno u suprotnosti s društvenim interesom. Ta je prepreka otklonjena prepuštanjem medicinskih fakulteta tržištu i farmaceutskoj industriji, čime patent postaje "poslovnom tajnom" tvrtke (Tyfield 2010: 69-70).

Sve je to bila "pravna" priprema u režiji države za njezino globalno pozicioniranje. Takav koncept "prava" već je uklopljen u "najrazvijenije i najmoćnije države svijeta, u zapadnjačko poimanje ugovora, prava vlasništva i u nove pravne režime koji služe nastavku pospješenja globalizacije" (Sassen 2003: 35). Savez za patente pridonosi stvaranju takvoga globalnog pravnog režima od 1986. do 1995, tijekom urugvajske runde pregovora o Općem ugovoru o carinama i trgovini (General Agreement on Tariffs and Trade, GATT) (Sells 1999; Ostry 2006). Gospodarski diplomati zapadnih zemalja de facto nisu pregovarali u ime svojih vlada nego u ime stanovitog Odbora za intelektualno vlasništvo. Odbor je nekoliko mjeseci prije početka pregovora osnovalo dvanaest multinacionalnih korporacija, od kojih su gotovo polovicu činile farmaceutske tvrtke. Cilj je bio ugraditi u međunarodni trgovinski pravni sustav Sporazum o trgovinskim aspektima intelektualnog prava vlasništva (Trade-Related Aspects of Intellectual Property Rights, TRIP). ${ }^{1}$ Osim što taj sporazum omogućuje ne-

\footnotetext{
Riječ je korporacijama Pfizer, Merck \& Co, Du Pont, Johnson \& Johnson, Bristol Myers Squibb. Najveća od navedenih korporacija, Pfizer, imala je i vodeću ulogu u Odboru za intelektualno vlasništvo. Kako je navela Susan Sells (1999: 171), pedesetak privatnika osmislilo je TRIP, koji su u njihovo ime ispregovarali i potpisali nacionalni političari i gospodarski diplomati, te je tako "u biti dvanaest korporacija oblikovalo javno pravo za cijeli svijet".
} 
kolicini tvrtki da samovoljno dižu cijene patentiranih lijekova na globalnoj razini, farmaceutski je kartel potisnuo svaku konkurenciju dobivši ekskluzivno pravo monopola na eksploatiranje svjetskog fonda biomedicinskog materijala.

$\mathrm{Ne}$ čudi stoga što je prvi autoritet međunarodnog zdravlja, Svetska zdravstvena organizacija (WHO), naglo bio zasjenjen Svjetskom trgovinskom organizacijom (WTO), koja nastaje zaključenjem urugvajske runde 1995. Za razliku od međudržavnog WHO-a, nadnacionalni WTO držao je TRIP kao ključ za diktiranje pravila u globalnome zdravstvenom sustavu. Bio je to prvi korak u procesu koji će omogućiti dramatičan porast broja aktera na prostoru globalnog upravljanja zdravljem. Taj je fenomen novost zato što se u sferi zdravstva pojavio razmjerno kasno. No, i on slijedi logiku koja se na Zapadu pojavila još potkraj 19. stoljeća u obliku imperijalizma. Razmatrajući "grabež za Afriku" kao kombinaciju kolonizacije europskih sila i širenja tržišta privatnih tvrtki, Hannah Arendt (2015: 128) ustanovila je da "imperijalizam nije izgradnja imperija i ekspanzija nije osvajanje". Država je kao politički prostor vezana za ograničeno mjesto, ali ne i za neograničenu produktivnost i poduzetništvo pojedinaca. Stoga se država ne može beskonačno širiti, dok privatni poslovni sektor to može. Načelo održavanja "potpunog zdravlja" čovječanstva državama je nezamislivo opterećenje koje nadilazi njihove ukupne regulacijske kapacitete i ekonomske resurse. Kako bi povećale svoju moć, one omogućuju neograničeno širenje prostora globalnog zdravlja ekspanzijom međudržavnih i nadnacionalnih organizacija, poslovanja farmaceutskih tvrtki i raznih privatnih inicijativa, od Fondacije Rockefeller do Bill and Melinda Gates Foundation.

Pogrešno bi bilo zaključiti da je riječ o imperijalizmu. Prošla su vremena kada se pod državom podrazumijevala suverena imperijalna sila, a pod tvrtkom paradržavna organizacija s privatnom vojskom, ustavom i zastavom. Interes glokalne države predstavlja velik analitički izazov, jer je na prostoru odvojenom od mjesta moć disperzirana, odnosno difuzna - ona je moć za sebe. Beck (2004: 92) tumači kako je moć koja se spontano i neograničeno raspršuje i vodi k neograničenoj proliferaciji aktera anonimna moć "bez središta, bez pripisivosti i bez jasne strukture odgovornosti". Takav globalni sustav nije na izbor nijednoj državi, a nije ni u vlasti bilo koje države; naime, globalizacija je "organizirana neodgovornost" (91). Difuzna moć znači da su i najdominantniji akteri u globalnom upravljanju zdravljem - farmaceutske tvrtke - ovisni o moći niza drugih aktera (dioničara, civilnog društva, konkurencije itd.). Primjerice, Južnoafrička Republika prekršila je 1997. odredbe TRIP-a uvevši zakon koji dopušta proizvodnju jeftinijeg lijeka za AIDS. Četrdeset farmaceutskih tvrtki podignulo je tužbu, ohrabreno političkom hajkom koju su protiv Južne Afrike pokrenuli američki potpredsjednik Al Gore i Europska unija. Međutim, pod udarom kritika civilnog društva i raznih nevladinih udruga, Gore je kao kandidat za predsjednika SAD-a u rujnu 1999. odustao od pritisaka. Farmaceutske tvrtke istog su mjeseca povukle tužbe, opravdavajući tu odluku navodno "postignutim kompromisom" (Halbert 2002: 272-274).

Organizirana neodgovornost globalnog poretka nije, dakle, imperijalizam, ali nije ni anarhija kao u predodžbi realističkih teorija međunarodnih odnosa. To je nered koji se objašnjava time da je moć difuzna ako je difuzan i interes države. Tome u prilog govori odnos razvijenih država prema Africi, konvencionalno percipiranoj "žrtvi" Zapada. Od kraja Hladnog rata države poput Ugan- 
de, Ruande, Etiopije i Čada širokogrudno prihvaćaju donacije i svaki oblik zapadnog tutorstva. No kako su režimi u tim državama nestabilni, a oružje im je jedina moneta koju trajno drže u optjecaju, tutorstvo Zapada prihvaćaju pod uvjetom da njihov vojno-sigurnosni kompleks ostane netaknutim (Fisher i Anderson 2015: 143). Programe za suzbijanje HIV-a/AIDS-a većina je afričkih zemalja prihvatila, ali donacije i pomoć za razvoj uglavnom završavaju u vojnom sektoru. Gušenje opozicije u zemlji i srljanje u sukobe sa susjednim državama perpetuiraju začarani krug beskonačnog ulaganja u socijalne programe i zdravstvo. I dok, primjerice, na sjednicama vlade Ugande, uz državne ministre, sjede i odluke donose predstavnici Svjetske banke i britanskoga Prekomorskog instituta za razvoj (Overseas Development Institute), vlasti otvoreno odbijaju podnositi izvještaje o korištenju donacija. Argument je uvijek jednak: pomoć za obrazovni i zdravstveni sustav nema smisla ako je država egzistencijalno ugrožena. Predsjednik Čada Idriss Déby prekršio je 2007. dogovor sa Svjetskom bankom prema kojemu je 86,5 posto zarade od naftovoda, koji je financirala banka, trebalo ići za socijalne programe, ponajviše za javno zdravstvo. Déby je sva sredstva potrošio na kupovinu oružja za borbu protiv lokalnih islamskih pobunjenika, uz opravdanje da je sigurnosni sektor prioritet.

Razlog zbog kojega takve prakse u Africi prolaze bez sankcija objašnjava se isključivo difuznim interesom države. Razvijene zemlje Zapada, koje izravno ili preko međunarodne organizacije daju pomoć tim režimima, u sklopu rata protiv terorizma opravdavaju sigurnosnu politiku lokalnih "saveznika". Mogu i Pentagon i Svjetska banka biti eksponenti istog interesa, ali to su dva odvojena birokratska svijeta. Nekoordiniranost, katkad i oštra suprotnost u odlukama, izraz je moći/interesa, koji se rasplinjuje u prolazu kroz razne državne urede, povjerenstva i odbore, međunarodne organizacije, privatne inicijative, neformalne skupine i fondove. Time se nameće ključno pitanje: ako je, naime, svjetsko društvo u riziku od globalnih pandemija, je li moguće oblikovanje odgovorne zdravstvene politike i učinkovita pristupa u obuzdavanju te prijetnje, a što bi bilo u interesu i države i globalnog poretka?

\section{Nova geopolitika i pandemija}

Farmaceutske su tvrtke dominantni, ali ne i odlučujući akteri u globalnom upravljanju zdravljem. Njihova dominacija proizlazi iz činjenice da djeluju u prostoru istodobnog zakona i bezakonja koje nadilazi svako pravo. Prema Becku, to je sfera translegalnosti. Budući da ne crpe legitimnost iz demokratskih izvora, korporativni se mandati opravdavaju samo jednim kriterijem - kriterijem "ekonomske racionalnosti tržišnog uspjeha" (Beck 2004: 113). Tržišni uspjeh mjeri se sposobnošću korporacije da trajno ulaže u nove biomedicinske inovacije. Ali, profitabilnost koja bi uvijek jamčila neko novo ulaganje ovisi isključivo o potrošačkoj moći. Kupovna je moć pak bitno teritorijalna: na Zapadu je jaka, u pojedinim državama u razvoju slabija ili slaba, a u većini država nikakva. Udio u prodaji farmaceutske industrije prema geografskim područjima to najbolje ilustrira: SAD/Kanada 74 posto, Zapadna Europa 13 posto, Latinska Amerika 2,4 posto, Azija/Pacifik 1,6 posto, Srednja i Istočna Europa 0,9 posto, Bliski istok 0,7 posto i Afrika 0,3 posto (Moerman 2006: 17). Korporativna dimenzija globalnog zdravlja sama biva reteritorijalizirana. Oko 90 posto sredstava uloženih u biomedicinska istraživanja troši se na proizvodnju lijekova za borbu protiv tipično "zapadnjačkih bolesti": dijabetesa, kardiovaskularnih 
bolesti, zloćudnih tumora i neuroloških poremećaja. Od 1975. do 2004. farmaceutska je industrija patentirala 1.556 lijekova, od kojih je 18 bilo protiv tropskih bolesti, a samo tri protiv tuberkuloze (Benatar, Gill i Bakker 2009: 348-351). Budući da tri milijarde ljudi ili 44 posto svjetskog stanovništva živi dnevno s manje od dva dolara per capita i nema pristup zdravstvu i osnovnim lijekovima, stvara se nova geopolitička zbilja: ekstremna neravnoteža globalnog zdravlja.

Zbog očajnih sanitarnih uvjeta, siromaštva, gladi i gotovo nikakvih higijenskih standarda $u$ nerazvijenim društvima, pandemija postaje imanentnom prijetnjom globalnom poretku. Bespredmetno je tražiti odgovornost farmaceutske industrije, jer je prema svojemu multinacionalnom karakteru ona bitno deteritorijaliziran entitet, a to znači da je potpuno uvjetovan tržišnom logikom globalnoga prostornog poretka. ${ }^{2}$ Uostalom, korporacija možda ima političko značenje, ali sama nije politički akter: može utjecati, ali ne i odlučivati. Za iznalaženje političkih rješenje za globalnu zdravstvenu sigurnost odgovorna je isključivo država. Treba istaknuti tri opcije koje država simultano razmatra i primjenjuje u suočavanju s tom problematikom. Prva se odnosi na nacionalnu sigurnost. Neovisno o kompleksnoj međuovisnosti, ta opcija nalaže jačanje

2 Većinu farmaceutskih tvrtki prate skandali i tužbe zbog neodgovornoga eksperimentalnog liječenja, uglavnom u zemljama Trećeg svijeta. No tu se ne može govoriti o neokolonijalizmu ili institucionalnom rasizmu, nego o činjenici da je logika tržišta nadređena motivima liječenja. Eksperimentiranje je naprosto jeftinije u nerazvijenim zemljama. Uostalom, "potpuno zdravlje" ostvarivo je ako se načelo kvantitete promiče na štetu kvalitete. To i objašnjava često štetne učinke lijekova. Kada je 2018. Johnson \& Johnson zaprimio stotisućitu tužbu u SAD-u, korporaciju su domaći potrošači optužili da stavlja profit ispred ljudi (Compton 2018). državnih sustava za unutarnju i vanjsku kontrolu prenosivih virusa. Druga je opcija nastavak depolitizacije, odnosno hiperglobalizacije zdravstva. U skladu $s$ globalističkim rezonom, neravnoteže uzrokovane poslovanjem farmaceutskih tvrtki treba prevladati privatnim inicijativama i filantropijom. Treća je opcija reforma specijaliziranih međunarodnih organizacija, poput WHO-a, tako da države prepuste određena ovlaštenja i omoguće veću autonomiju međunarodnim organizacijama u donošenju odluka i djelovanju. Nijedna opcija nije strogo određen državni interes, nego sporadično sve tri oblikuju državnu politiku u globalnom upravljanju zdravljem i dodatno pridonose općem neredu.

Prvu je opciju u literaturi međunarodnih odnosa popularizirala razmjerno mala skupina autora, koju Sara E. Davies (2010) naziva "etatistima". Etatizam je varijanta realizma i temeljna mu je pretpostavka jednostavna: pojedinac ne može biti zdrav i siguran ako mu to država ne omogući. Među najistaknutije predstavnike tog pristupa ubrajaju su Andrew Price-Smith (2002), koji je razvio koncept "zdravstvene sigurnosti", i David Findler (1998). Findler uvažava sociološke posljedice globalizacije na državu i njezinu suverenost, kao i činjenicu da postvestfalsko doba postavlja sasvim nove izazove. Glavni je problem što kontrola infektivnih bolesti nije uopće na listi prioriteta nerazvijenih država. Njima nedostaju jaka politička vodstva i ekonomski resursi. Stoga "oblikovanje nacionalnog interesa takvih država treba ili ohrabrivati, ili nametnuti vanjskim pritiscima i poticanjima" (Findler 1999: 49). Findler je nedorečen u odgovoru na pitanje o kakvim je pritiscima i poticanjima riječ.

Umjesto da istakne nerazvijeni sustav javnog zdravstva u Trećem svijetu kao središnji problem, etatizam je primarno usmjeren na sigurnosne koncepcije 
obuzdavanja pandemije. Pojava te perspektive duguje ponajviše terorističkim akcijama, kao što su napad sarinom u tokijskom metrou 1995. ili napad antraksom u pismima u SAD-u 2001. Biosigurnost postupno je postajala jednim od prioriteta nacionalne sigurnosti, poglavito pod administracijom predsjednika Baraka Obame (Koblentz 2010). On je 2009. donio sveobuhvatnu biosigurnosnu strategiju koja razmatra cijeli niz bioloških prijetnji (Obama 2009). Strategija suzbijanja "bioloških prijetnji" nalaže istraživanje patogena prenosivih virusa, bilo da se pojave u obliku pandemije bilo kao potencijalno oružja u rukama terorista. Država treba kontrolirati najrecentnija biomedicinska istraživanja posredstvom raznih privatno-javnih nadzornih povjerenstava, poput Ekspertne skupine za biološke znanosti (Biological Science Expert Group), koju su 2007. osnovale obavještajne službe u "suradnji" s biomedicinskim znanstvenicima. Također, Findlerova "postvestfalska" realnost zahtijeva i prekomorski angažman. Kao što postoje AFRICOM i CENTCOM, američka vojna zapovjedništva zadužena za područja zapadne Afrike i Bliskog Istoka, tako je američko ministarstvo obrane osnovalo laboratorije za istraživanje i kontrolu infektivnih bolesti u čak dvadeset država. No svrstavanje pandemijske prijetnje $\mathrm{u}$ isti rang $s$ prijetnjom terorističkih napada biološkim oružjem ukazuje na to da nije riječ o politici upravljanja globalnim zdravljem. Etatizam je "usredotočen na obranu i obuzdavanje, a ne na korijene problema te, osim infektivnih virusa, zanemaruje sve ostale probleme javnog zdravstva" (Davies 2010: 1180).

Prema globalističkoj perspektivi, filantropija je rješenje za prevladavanje globalne zdravstvene neravnoteže. Razne inicijative, poput Gatesove fondacije, redovno izdvajaju milijune dolara za proizvodnju cjepiva te ulažu $u$ istra- živanja lijekova za HIV/AIDS, malarije i tuberkuloze. Filantropski globalizam žestoko je suprotstavljen ideji razvijanja sustava javnog zdravstva. Poduzetnici zagovaraju "tržišna rješenja" ne samo zbog ideoloških, nego i pragmatičnih razloga: filantropija pogoduje njihovu poslovanju i donosi dodatnu zaradu (Schwab 2020). ${ }^{3}$ Kako je pokazala Laurie Garret, sklonost političkih elita privatnim inicijativama postala je očitom nakon financijskog kraha 2008. i globalne recesije koja se kritično odrazila na globalno zdravlje. U odgovoru na taj izazov, multilateralne organizacije, ponajprije WHO, pokazale su se ne samo podkapacitiranima, nego i neodgovornima $u$ upravljanju sredstvima. Ispostavilo se da je 2010. Globalni fond za borbu protiv HIV-a/AIDS-a, malarije i tuberkuloze imao neobjašnjivu proračunsku "rupu" od pet milijarda dolara. Kada je taj fond sljedeće godine skandalozno zatražio još 25 milijarda dolara donacija, bijesne donatorske države okrenule su se filantropskim inicijativama (Garret 2013: 6-8). Zaokret provodi britanski premijer David Cameron, koji je na skupu G8 u Londonu 2012. potaknuo zapadne partnere da svoju potporu preusmjere na Globalni savez za cjepiva koji, uz Svjet-

\footnotetext{
3 Prema istraživanju Tima Schwaba (2020), filantropija je unosan posao, jer takva aktivnost oslobađa tvrtku od plaćanja poreza. Oslobođen od plaćanja poreza, Gates je 2018. uštedio četiri milijarde dolara. Istodobno, filantropija je dobra propaganda koja povećava ugled i utjecaj poduzetnika. Gatesova fondacija jedna je od rijetkih koja ne ulaže u neprofitne organizacije nego isključivo u privatni sektor. Donira uglavnom farmaceutskoj industriji kako bi proizvodila određene lijekove i cjepiva. Pritom je u nekim tvrtkama suvlasnica, što upućuje na sukob interesa. Prema priznanju jednoga bliskog Gatesova suradnika, "Gates je u privatnim razgovorima uvijek žestoko napadao sustav javnog zdravstva... Govorio je kako je to čisto bacanje novaca, da je to nedjelotvoran sustav i da od njega neće dobiti ni centa za razvoj javnog zdravstva" (Martens i Seitz 2015: 35-36).
} 
sku banku, financira, a najvećim dijelom i kontrolira, Gatesova fondacija (The Guardian, 2011).

Sprega države i filantropije podiže netransparentnost na novu razinu. U Globalnom savezu za cjepiva odluke se ne donose na multilateralnoj razini, kao u WHO-u (dakle, ne uključuju države kojima je pomoć namijenjena), nego unutar jedne hibridne strukture u kojoj, uz nekoliko predstavnika vlasti i međunarodnih organizacija, glavni utjecaj imaju farmaceutski divovi GlaxoSmithKline, Merck, Novartis i Pfizer (Chow i dr. 2016). Filantropske inicijative postižu globalnu dominaciju infiltracijom u gotovo sve relevantne organizacije. Gatesova fondacija najveći je donator WHO-a poslije SAD-a te je od 2010. Gates posebni savjetnik glavnog tajnika UN-a u skupini za promidžbu milenijskih razvojnih ciljeva (Martens i Seitz 2015: 1819). Margaret Chan, nekadašnja glavna tajnica WHO-a, izjavila je 2014. kako je proračun kojim ona raspolaže "strogo namjenski" prema diktatu "donatorskih interesa". A interes je, kako kaže Chan, jednokratno uložiti mnogo novaca kako bi se riješio neki neposredan zdravstveni izazov. Čim je izazov prevladan, "prestaje pristizati novac" i u WHO-u se "počinju dijeliti otkazi" (nav. u: Chow i dr. 2016: 14). Filantropija kratkoročno ublažava problem omogućavanjem veće dostupnosti lijekova nerazvijenim društvima. No ona ga istodobno i produbljuje, jer djeluje unutar sustava i za sustav organizirane neodgovornosti, koji upravo generira ekstremne neravnoteže i rizike u globalnom zdravlju.

Što se moguće reforme specijaliziranih agencija tiče, posebnu pažnju treba posvetiti slučaju Svjetske zdravstvene organizacije (WHO). Tijekom devedesetih godina prošlog stoljeća pred WHO-om je bio izbor: prepustiti se potpunoj organizacijskoj atrofiji ili se prilagoditi zahtjevima globalnog uprav- ljanja zdravljem. ${ }^{4}$ WHO se opredijelio za potonje. Prilika se pojavila nakon terorističkih napada 11. rujna 2001. Davies tvrdi da je WHO nastojao monopolizirati diskurs sekuritizacije zdravlja kako bi osujetio etatistički zahtjev za jačanjem samostalne nacionalne kontrole prenosivih virusa (Davies 2008: 296). U suradnji s kanadskom vladom, 2002. razvija mehanizam za globalno upozorenje i reagiranje na izbijanje pandemija (Global Outbreak and Alert Response Network) te na sebe preuzima punu odgovornost za nadziranje infektivnih bolesti. I zaista, kako je primijetio Fidler, WHO je obuzdavanjem SARS-a i "ptičje gripe" između 2003. i 2010. demonstrirao sposobnost globalnog upravljanja zdravljem. Ipak, najveće udjele u financiranju WHO-ova mehanizma snosile su SAD, Kanada, Australija i Europska unija. Zapad je dopustio WHO-u da zauzme poziciju globalnog autoriteta jer je "time prebacio odgovornost na jedno 'neutralno' međunarodno tijelo i tako izbjegao optužbe za imperijalno proširivanje" (Davies 2008: 309). Istodobno, većina objekata za nadzor infektivnih patogena nalazi se na Zapadu. Reforma WHO-ovih regulativa, koje bi nalagale obvezatnu suradnju država s tom organizacijom u slučaju izbijanja epidemije, odgađane su i kočene. Dakle, WHO je

4 Na zasjedanju svoga vrhovnog tijela Međunarodne zdravstvene skupštine (International Health Assembly) 1995, vodstvo WHO-a ukazalo je na nekoliko bitnih problema s kojima se organizacija suočava. Prvo, hitno je trebalo proširiti zastarjele i prevladane ingerencije nadzora koje su još uvijek bile ograničene na koleru, kugu i žuticu. Drugo, WHO djeluje isključivo u suradnji s vladama država-članica, odnosno ovisi o tome hoće li u slučaju epidemije vlada obavijestiti organizaciju. To se uglavnom ne događa jer vlade djeluju samostalno. Treće, oblici suradnje WHO-a i države u slučaju epidemije uopće nisu definirani pravilnikom. I četvrto, WHO nije imao nikakav mehanizam za poticaj država da surađuju (World Health Organization, 2002). 
bio proceduralno ograničavan i nedostatno financiran u globalnom upravljanju zdravljem.

Međutim, uloga te međudržavne organizacije već je uvelike prilagođena zakonitostima globalnog prostora. Indikativna je njezina reakcija na prvi pravi globalni izazov: izbijanje pandemije ebole u zapadnoj Africi u ožujku 2014. Ebola je zarazila milijun i pol ljudi te odnijela 11.265 života. Pandemija se mjesecima rapidno širila, ali WHO je tek u kolovozu proglasio globalno izvanredno stanje. Kasnije su mediji otkrili da je WHO itekako bio upućen u ozbiljnost stanja na terenu, ali je odbijao proglasiti izvanredno stanje. U javnosti je odbacivao upozorenja organizacije Liječnici bez granica (Médecins Sans Frontières) te je glasnogovornik WHO-a Gregory Hartl izjavio: "Vi biste zaista poremetili ekonomski život jedne zemlje ili regije samo zato što je potvrđeno 130 slučajeva zaraze?" (Associated Press, 2015). Prometnut na prostor globalnog zdravlja, WHO djeluje kao katalizator interesa za održavanjem globalnog poretka. U prvom desetljeću 21. stoljeća sekuritiziranjem zdravlja priklonio se Zapadu. Danas je kineski utjecaj na WHO više nego očit. Nema dvojbe o tome da su kineske vlasti odgovorne za izbijanje pandemije koronavirusa, kako zbog sustavnog zataškavanja stvarne prirode patogena tako i zbog neobavještavanja WHO-a o epidemiološkom stanju u žarišnom gradu Wuhanu. WHO je najprije odugovlačio s proglašenjem globalnoga izvanrednog stanja, koje je proglasio tek 30 . siječnja 2020. Potom je odbijao primiti u članstvo Tajvan, državu koju Kina ne priznaje (BBC News, 2020). Naposljet$\mathrm{ku}$, dan prije proglašenja globalnoga opsadnog stanja, dr. Tedros Adhanom Ghebreyesus, glavni tajnik WHO-a, pohvalio je kineske vlasti za impresivan rad i upravljanje krizom "koje je sprije- čilo da se virus proširi svijetom" (Joseph 2020).

\section{Zaključak}

Kako teorije međunarodnih odnosa mogu objasniti globalno upravljanje zdravljem i problematiku pandemije? Je li interes razvijenih država da održavaju epidemiološki rizičan poredak? Je li prijetnja globalne pandemije podnošljiva cijena držanja nerazvijenog svijeta u podređenome i o donacijama ovisnu položaju? Odgovori na ta pitanja ovise isključivo o tome kako se tumači moć političkog interesa. Za realizam nema dvojbi ako se prihvati da je globalni poredak anarhičan. Države su naprosto primorane boriti se za moć: ili zato što je ona uvjet njihova opstanka, ili zbog sigurnosne dileme, ili zbog stjecanja statusa. Demonstracija državne moći u svakom je slučaju odlučujuća za ishode u međunarodnoj politici. Primjerice, SAD je 1999. s pozicije sile zaprijetio Tajlandu trgovinskim ratom ako proizvede generički lijek za AIDS. S druge strane, Indonezija je 2007, pod egzistencijalnom prijetnjom pandemije "ptičje gripe", proglasila "suverenost nad virusom" i odbila suradnju s WHO-om. ${ }^{5}$ Ali, takva su objašnjenja još površinska i ne dotiču bit problema.

Problematika globalnog zdravlja ne može se objasniti ni iz perspektive liberalnog internacionalizma zato što su implikacije međudržavne suradnja unutar globalnog poretka goleme, kako se vidjelo na primjeru WHO-a. Uvjerljivije su stoga postavke kritičkih i marksističkih teorija koje globalno upravljanje zdravljem nastoje objasniti logikom im-

5 Prema realističkom ključu, doista je posrijedi bio klasičan primjer samopomoći. Indonezijska je vlada, sukladno međunarodnoj obvezi, predala patogene WHO-u. No cjepivo je proizvela australska tvrtka CSL Ltd, i rasprodala ga po visokoj cijeni uglavnom razvijenim državama koje uopće nisu bile pogođene pandemijom. 
perijalizma. Paradigma imperija podudara se s predodžbom Zapada kao centra koji pomoću filantropije kao dimne zavjese za bogaćenje farmaceutskih korporacija drži poluperiferiju i periferiju u trajno ovisnom položaju. Međutim, tu nije riječ ni o anarhiji ni o imperiju. Realizam promatra moć decentralizirano, kao materijalnu sposobnost raspoređenu po državama. Imperijalizam vidi moć koncentriranu u jednom centru, koja se u koncentričnim krugovima širi po poluperiferiji i periferiji. Obje su perspektive utemeljene u materijalističkoj - bitno teritorijalnoj - predodžbi o moći koja je vezana za određeni lokalitet ili lokalitete.

Globalni prostor odvojen od mjesta generira posve drugačiji oblik moći difuznu moć. Teorija međunarodnih odnosa koja bi se mogla pokazati najpri- kladnijom u naznačenoj analitičkoj perspektivi jest konstruktivizam Alexandra Wendta (2009). Wendt je, pod utjecajem Giddensa, konstruirao pojam sukonstitutivnosti aktera i strukture. Države svojim interakcijama oblikuju prostor, koji povratno preoblikuje njihove identitete. Identiteti, pak, po svojoj prilici uvjetuju i oblikuju interese država. Promatranje takvog interesa jedne "nove normativnosti" države mora biti u fokusu. Globalni je prostor ovisan o difuznim tokovima moći i isprepleten često suprotstavljenim i kontradiktornim motivima i ingerencijama. Prostor difuzne moći stoga pretpostavlja da je i interes države difuzan. Ustvari, interes države u upravljanju globalnim zdravljem uopće se ne može misliti kao nešto konkretno i jedinstveno. Nered i politička zbrka što ih je izazvala pandemija koronavirusa govore tome u prilog. 


\section{Literatura}

Aginam, Obijiofor. 2005. Global Health Governance: International Law and Public Health in a Divided World. Toronto: University of Toronto Press.

Arendt, Hannah. 2015. Izvori totalitarizma. Zagreb: Disput.

Associated Press. 2015. Political considerations delayed WHO Ebola response, emails show. https://www.cbsnews. $\mathrm{com} /$ news/political-considerationsdelayed-who-ebola-response-emailsshow/ (pristupljeno 11. rujna 2020).

BBC News. 2020. Why Taiwan has become a problem for WHO. https://www. bbc.com/news/world-asia-52088167 (pristupljeno 17. rujna 2020).

Beck, Ulrich. 2003. Što je globalizacije? Zablude globalizma - odgovori na globalizaciju. Zagreb: Vizura.

Beck, Ulrich. 2004. Moć protiv moći u doba globalizacije: nova svjetskopolitička ekonomija. Zagreb: Školska knjiga.

Benatar, Solomon R., Gill, Stephen, Bakker, Isabella. 2009. Making Progress in Global Health: The Need For New Paradigms. International Affairs. (85) 2: 347-371.

Borowy, Iris. 2009. Coming to Terms WIth World Health: The League of $\mathrm{Na}$ tions Health Organization 1921-1946. Frankfurt: Peter Lang.

Charter of World Health Organization. 1946. https://www.who.int/governance/eb/who_constitution_en.pdf?ua=1 (pristupljeno 24. kolovoza 2020).

Chow, Heidi i dr. 2016. Gated Development: Is the Gates Foundation always a force for good? London: Global Justice Now.

Council on Foreign Affairs. 2019. Global Health Regime. https://www.cfr.org/ report/global-health-regime (pristupljeno 12. rujna 2020).
Compton, Kristin. 2018. Johnson \& Johnson. https://www.drugwatch.com/ manufacturers/johnson-and-johnson/ (pristupljeno 31. kolovoza 2020).

Davies, Sara E. 2008. Securitizing Infectious Disease. International Affairs. (84) 2: 295-313.

Davies, Sara E. 2010. What Contribution Can International Relations Make To The Global Health Agenda? International Affairs. (86) 5: 1167-1190.

Fee, Elizabeth, Cueto, Marcu, Brown, Theodore M. 2016. At the Roots of The World Health Organization's Challenges: Politics and Regionalization. https://www.ncbi.nlm.nih.gov/ pmc/ articles/PMC5055806/ (pristupljeno 28. kolovoza 2020).

Findler, David. 1998. Microbialpolitik: Infectious Diseases and International Relations. American University International Law Review. (14) 1: 1-53.

Fisher, Jonathan, Anderson, David M. 2015. Authoritarianism and the Securitization of Development in Africa. International Affairs (91) 1: 131-152.

Garret, Laurie. 2013. Existential Challenges to Global Health. New York: New York University.

Giddens, Anthony. 1990. The Consequences of Modernity. Stanford: Stanford University Press.

Halbert, Debora. 2002. Moralized Discourses: South Africa's Intellectual Property Fight for Access to AIDS Drugs. Seattle Journal for Social Justice. (1) 2: 257 -295.

Hoen, Ellen F. M. 't. 2009. The Global Politics of Pharmaceutical Monopoly Power. Diemen: AMB Publishers.

Howard-Jones, Norman. 1975. The Scientific Background of International Sanitary Conferences. Ženeva: World Health Organization. 
Joseph, Andrew. 2020. WHO praises China's response to coronavirus, will reconvene expert committee to assess global threat. https://www.statnews.com/2020/01/29/who-reconvene-expert-committee-coronavirus/ (pristupljeno 14. rujna 2020).

Kamradt-Scott, Adam. 2013. Problems and Prospects For Health in the Twenty-First Century. U: Herman, Sophie, Williams, David (ur.). Governing the World? Cases in Global Governance. New York: Routledge, str. 128-141.

Koblentz, Gregory D. 2010. Biosecurity Reconsidered: Calibrating Biological Threats and Responses. International Security. (34) 4: 96-132.

Larson, James J. 1996. The World Health Organization's Definition of Health: Social versus Spiritual Health. Social Indicators Research. (38) 2: 181-192.

Leon, Joshua K. 2015. The Rise of Global Health: The Evolution of Effective Collective Action. Albany: State University of New York Press.

Martens, Jens, Seitz, Karolin. 2015. Philantropic Power and Development: Who Shapes the Agenda? Aachen: Bischöfliches Hilfswerk MISEREOR.

Moerman, Lee C., Van der Laan, Sandra L. 2006. TRIPS and the pharmaceutical industry: Prescription for profifit? https://ro.uow.edu.au/commpapers/ 217 (pristupljeno 17. kolovoza 2020).

Norberg, Johan. 2003. In Defense of Global Capitalism. Washington: Cato Institute.

Obama, Barack. 2009. National Strategy For Countering Biological Threats. Washington: National Security Council.

Ostry, Sylvia. 2006. The World Trading System: In The Fog Of Uncertanity. Review of International Organization. (1) 1: 139-152.

Price-Smith, Andrew. 2002. The Health of Nations: Infectious Disease, Envi- ronmental Change, and Their Effects on National Security and Development. Massachusetts: Massachusetts Institute of Technology.

Raos, Višeslav. 2014. Teritorijalnost $i$ identitet: Istarski demokratski sabor $i$ Sjeverna liga. Zagreb: Fakultet političćkih znanosti.

Ruger, Jennifer P. 2005. The Changing Role of the World Bank in Global Health. https://www.ncbi.nlm.nih. gov/ pmc/articles/PMC1449852/ (pristupljeno 13. rujna 2020).

Safranski, Rüdiger. 2008. Koliko globalizacije čovjek može podnijeti? Zagreb: Ljevak.

Sassen, Saskia. 2003. Protugeografije globalizacije. Zagreb: Multimedijalni institut.

Schwab, Tim. 2020. Bill Gates's Charity Paradox. https://www.thenation.com/ article/society/bill-gates-foundationphilanthropy/ (pristupljeno 17. rujna 2020).

Sells, Susan K. 1999. Multinational Corporations as Agents of Change: The Globalization of Intellectual Property Rights. U: Cutler, Clair, Haufler, Virginia, Porter, Tony. (ur.), Private Authority and International Affairs. Albany: SUNY Press, str. 169-197.

The Covenant of the League of $\mathrm{Na}$ tions. 1924. https://avalon.law.yale. edu/20th_century/leagcov.asp (pristupljeno 26. kolovoza 2020).

The Guardian. 2011. David Cameron defends international aid rise with vaccine pledge. Dostupno na: https://www. theguardian.com/global-development/ 2011/jun/11/david-cameron-international-aid-vaccine (pristupljeno 11. rujna 2020).

Tyfield, David. 2010. Neoliberalism and the Global Knowledge Economy. U: Birch, Kean, Mykhnenko, Vlad. (ur.), The Rise and Fall of Neo-liberalism: The Collapse of an Economic Order? 
London i New York: Zed Books, str. 60-76.

Wendt, Alexander. 1999. Social Theory of International Politics. Cambridge: Cambridge University Press.

Woolhouse, Mark E. J. i dr. 2008. Temporal trends in the discovery of human viruses. https://www.ncbi.nlm.nih.gov/pmc/ articles/PMC2475551/ (pristupljeno 17. rujna 2020).

World Health Organization. 2002. Global Crisis - Global Solutions: Managing
Public Health Emergencies of International Concern Through The Revised International Health Regulations. Ženeva: WHO Department of Communicable Disease Surveillance and Response.

Yi-Jui Wu, Harry. 2015. World citizenship and the emergence of the social psychiatry project of the World Health Organization, 1948-c.1965. History of Psychiatry. (26) 2: 166-181.

Zorko, Marta. 2018. Geopolitika i teritorijalnost. Zagreb: Jesenski i Turk. 


\section{Global Health and Interest of the State}

Abstract The coronavirus pandemic is the last in a row of global crises that have shed light on the reach and the limitations of international relations theories, especially contemporary realism. The conventional analytical framework that narrows international political relations down to just two levels of analysis, the national and the international, seems inadequate for considering the issue of global health management. This article, therefore, intends to highlight the complex character of and the logic behind global spatial order in the area of global health from the perspective of the sociology of globalization. The implications for the state and its interest are reflected in the dramatic proliferation of different private actors, from pharmaceutical industries to various corporate and philanthropic initiatives. Their expansion has facilitated the positioning of particularly Western economic and military forces in the power arena of global management. However, market logic and the diffuse power of global health have been generating serious global health imbalances between the developed and underdeveloped societies, between strong and weak states. Global disproportion i.e. the catastrophic sanitary conditions in the Third World are in fact the root of potential threats and pandemic outbreaks which, in turn, threaten the very global order. The crucial question thus becomes: What is actually the strategic interest of the state in a global health era?

Key words global management, global health, the state, interest, international organization 